\title{
As formas do real: a representação da cidade em Eles eram muitos cavalos
}

Rejane Cristina Rocha ${ }^{1}$

Car j'ai de chaque chose
extrait la quintessensse

Tu m'as donné ta boue et $j^{\prime}$ en ai fait $l^{\prime}$ r $^{2}$ Baudelaire

\section{Introdução}

Os dois versos que propomos como epígrafes para esta reflexão funcionam como uma espécie de elo a atar os dois momentos histórico-literários - e, por conseguinte, as duas obras, objetos deste estudo, - sobre os quais lançaremos o nosso olhar. Em outra ocasião ${ }^{3}$, discutimos de que forma o termo "fascinação" poderia ser eleito para melhor descrever a relação entre o artista, desde o início da modernidade, e a cidade. $O$ misto de atração e repulsa que está implícito no significado do vocábulo, emerge desses versos de Baudelaire, que olha para a cidade de finais do século XIX com o olhar crítico daquele que a sabe como o repositório de todas as tensões de que a modernidade - e as novas relações de trabalho, de consumo e de produção que a caracterizam desde o seu surgimento - é agregadora e, ao mesmo tempo, a sabe, também, como fonte inesgotável de material poético.

Questionar, assim, a representação da cidade moderna pela literatura contemporânea é, a par de observar de que forma o espaço urbano de hoje fornece temas e motiva formas para a literatura de hoje, compreender que há uma tradição construída desde o século XIX, quando da emergência dos primeiros centros urbanos, no que diz respeito a essa representação

\footnotetext{
${ }^{1}$ Docente do Programa de Pós-Graduação em Estudos de Literatura e do Departamento de Letras da Universidade Federal de São Carlos (UFSCar), São Carlos, Brasil. Membro do grupo de pesquisa "Realismo e realidade na ficção brasileira contemporânea” (Cnpq/UFSCar). E-mail: rejane@ufscar.br 2 "De cada coisa, pois, extraí-lhe a quintessência/ Me deste a lama e transformei em ouro."

${ }^{3}$ Trata-se do artigo "Arquitetura dos contrastes: uma leitura de Eles eram muitos cavalos" (Rocha, 2009).
} 
literária. Descrever tais topoi de maneira minuciosa não é o objetivo deste artigo que, entretanto, pretende observar de que forma a tradição moderna que se construiu em torno da representação da cidade pode ser identificada - em suas recorrências e/ou transformações - na literatura que, no Brasil, no início do século XXI, visita o espaço urbano, fascinada com o que nele há de lama e que pode ser transmudado no ouro da representação estético-literária.

Por isso, para analisar o romance Eles eram muitos cavalos, de Luiz Ruffato, publicado em 2001, nos deteremos, antes, naquela que foi considerada a primeira obra do Modernismo brasileiro e que, não por um acaso já que o tema da cidade é frequentemente visitado pela literatura, sendo ele mesmo considerado um topos moderno, desde Baudelaire - elege a paisagem urbana como temática central, Pauliceia desvairada, de Mário de Andrade. Para tanto, é preciso compreender o que, da representação da São Paulo marioandradina, extrapola a descrição do objeto-cidade e nos informa sobre a própria configuração da Modernidade, uma vez que

O poder de atração e repulsão da cidade tem fornecido temas e posturas que atravessam profundamente a literatura, na qual a cidade aparece mais como metáfora do que como lugar físico. De fato, para muitos escritores, a cidade chegou a se converter numa analogia da própria forma (...) E se o Modernismo é uma arte especificamente urbana, em parte é porque o artista moderno, tal como seus semelhantes, foi capturado pelo espírito da cidade moderna, que em si é o espírito de uma sociedade tecnológica moderna. (Bradbury; McFarlane, 1999, p. 77)

Assim, estão postos os objetivos desta reflexão, quais sejam os de analisar a representação da cidade contemporânea na obra Eles eram muitos cavalos, a partir do pressuposto de que em tal representação é possível identificar invariantes temático-formais que remetem não só ao objeto da representação, cidade, mas, sobretudo, a um modo de representação especificamente moderno - por isso Pauliceia desvairada surge, no horizonte deste artigo, como obra à qual se recorrerá para identificar tais invariantes. Nesse percurso, os Pétits poèmes en prose, de Charles Baudelaire, será inserido nas reflexões desde uma visada que os identifica como ponto de partida de uma representação ambígua da cidade, que perdurará, acreditamos, até os nossos dias. Em decorrência disso, as diferenças entre os gêneros - prosa, poesia e prosa poética, respectivamente - serão colocadas em segundo plano para esta análise. De qualquer modo, e isso será discutido em momento oportuno, parece que o tema, "cidade moderna", impõe certo recorte estrutural que beneficia o hibridismo de gênero, como se "o caos cultural alimentado pela 
cidade populosa em crescimento constante (...) fosse reproduzido como análogo caos, contingência e pluralidade nos textos literários modernos" (Strong apud Bradbury; McFarlane, 1999, p. 78).

\section{Baudelaire: cidade real e irreal}

Para compreender as relações ambivalentes - de fascinação, de simultâneos atração e repúdio - estabelecidas entre o artista moderno e a modernidade e, por conseguinte, entre artista moderno e cidade moderna, há que se remeter ao fato de que este fenômeno, desde a sua aurora, não se estabeleceu apenas em sentido espiritual, no que tange às subjetividades, às perspectivas temporais, às investigações artístico-filosóficas, mas também em sentido material, uma vez que a emergência e consolidação da sociedade industrial e do capitalismo como sistema financeiro é face inextricável do que entendemos por modernidade (Berman, 2007, p. 158 e ss.; Kumar, 1997). A recém-surgida cidade moderna, em meados do século XIX, é o locus privilegiado em que se podem observar materialmente as contradições da modernidade: de um lado, as capitais culturais, para as quais convergiam as novidades cosmopolitas das artes, da moda, dos comportamentos; de outro, a caoticidade do espaço que, em permanente revolução arquitetônica, expulsava para as suas margens os espoliados do sistema capitalista.

Baudelaire não só foi observador privilegiado dessa ambivalência fundamental, como viu, sob os seus pés, de que forma se erigiria a cidade moderna por excelência, a Paris do século XIX. As investidas de Haussmann na arquitetura parisiense e tudo o que elas acarretaram no que diz respeito às relações sociais estabelecidas na geografia da cidade - obviamente, a substituição das ruelas estreitas e cortiços pelos elegantes bulevares e modernas passagens resultou em novas formas de relacionamento social - foram testemunhadas por Baudelaire, que viu de que maneira a modernização do espaço físico acarretaria (ou não) a modernização espiritual das pessoas aí estabelecidas. O contraponto que se inseriu anteriormente não é simplesmente retórico; antes, serve para explicitar uma confusão deliberadamente construída entre a modernização como progresso material e modernização enquanto progresso espiritual o que mais de uma vez acarretou a irritação do ensaísta Baudelaire. As duas esferas não se confundem em absoluto, embora os discursos da modernização, até os dias atuais, pautem-se nessa falaciosa identidade. A obra de Baudelaire antevê tal confusão e, ora adere a ela, ora a desmascara criticamente.

A ambivalência da modernidade e do espaço moderno, a cidade, 
insere-se, assim, na própria obra baudelairiana. Marshal Berman (2010, p. 158 e ss.) nota, na poesia e prosa literárias de Baudelaire, bem como em sua obra crítico-ensaística, uma postura que vai do mais absoluto encantamento, à qual denomina "Modernismo pastoral", a mais veemente recusa da modernidade e do modo de vida moderno, à qual denomina "Modernismo antipastoral". No primeiro caso, insere-se o famoso ensaio dedicado a Constantine Guys, "O pintor da vida moderna", que, a par de construir uma argumentação elogiosa do referido artista, constrói um libelo à cidade moderna (e às relações sociais que aí se estabelecem, ao comportamento das massas, à moda). No segundo caso, estão as reflexões presentes no ensaio "Sobre a moderna ideia de progresso aplicada às Belas Artes", no qual o escritor redige um verdadeiro libelo condenando aquela confusão à qual nos referimos pouco acima, entre modernização material e modernização espiritual.

Além dessas posições diametralmente opostas, Berman (id.) chama a atenção para o fato de que surgem, ainda, nos escritos de Baudelaire, apontamentos mais aprofundados e, porque mais ambivalentes, mais próximos do pensamento moderno. Trata-se dos poemas de Spleen de Pa$\mathrm{ris}^{4}$, que, de maneira fragmentada e em formato ainda pouco experimentado até então - a prosa poética - , deixa-se contaminar não só pelo encantamento em relação ao novo espaço urbano que surgia, como também antevia, em seu gérmen, os problemas advindos de uma modernização econômica pautada na desigualdade social. Como afirma Berman (2010, p. 161), a obra de Baudelaire "contém várias visões distintas da modernidade (...) que parecem opor-se umas às outras" e são essas ambivalências que, no caso de Spleen de Paris, sedimentam toda a representação da modernidade e da cidade moderna ali presentes.

Se frequentemente Baudelaire foi lido como o poeta que deu início à representação literária da cidade moderna, interessa-nos, neste artigo, observar o quanto ele também iniciou, como afirma Hamburger (2007, p. 373), uma reação a ela. Isso porque, como antecipamos em nossa hipótese, acreditamos que obras posteriores, seja ela a modernista Pauliceia desvairada, seja ela a contemporânea Eles eram muito cavalos reiteraram e recriaram, posteriormente, temas e modos de representação inaugurados por Baude-

\footnotetext{
${ }^{4}$ Como esclarece o prefácio de Ivo Barroso na edição bilíngue publicada em 2006 pela Editora Record, Baudelaire chamou a um mesmo conjunto de poemas de Spleen de Paris e de Petits poèmes en prose - além de Poemas noturnos, $O$ caminhante solitário, $O$ clarão e a fumaça e Pequenos poemas licantropos. Embora o título mais popular ainda seja Spleen de Paris, doravante utilizaremos a denominação escolhida pela edição brasileira, a qual consultamos para este trabalho, Pequenos poemas em prosa.
} 
laire e consolidados por seus seguidores. Perseguiremos, então, de forma bastante breve, alguns dos temas relacionados à cidade moderna presentes em Baudelaire ${ }^{5}$ e discutiremos o modo como, formalmente, ele escolheu representá-los; tal percurso abrirá caminho para, então discutirmos as obras de Mário de Andrade e de Luiz Ruffato.

*a rua, a multidão, os olhos que veem a cidade

Os Pequenos poemas em prosa contêm um epílogo que funciona como um esclarecimento:

Com o coração feliz subo para a montanha

De onde posso contemplar a cidade inteira,

Hospital, lupanar, purgatório, inferno, prisão.

Onde toda a enormidade ${ }^{6}$ floresce como uma flor.

Sabes bem, ó Satã, dono de minha angústia,

Que eu não fui lá para derramar meu pranto;

Mas como um velho libidinoso de uma velha amante,

Quero inebriar-me com a enorme prostituta

Cujo encanto infernal me rejuvenesce sempre.

Que durmas ainda nos lençóis da manhã,

Pesada, obscura, resfriada, ou que te exibas

Entre os véus da noite bordados a ouro fino;

Eu te amo, ó capital infame! cortesãs

E bandidos, aos quais ofereces prazeres

Incompreendidos pelos vulgares profanos.

Precedido pelos 50 pequenos fragmentos de prosa poética que oferecem ao leitor uma série de instantâneos da vida na cidade, absolutamente variados no que diz respeito ao recorte temático, o epílogo tem a função de reunir, sob um mesmo ponto de vista, a partir de um mesmo ângulo, o que, desavisadamente, poderia ser lido como peças reflexivo-poéticas isoladas, sem conexão.

\footnotetext{
${ }^{5}$ Nesse percurso, retomaremos algumas das reflexões seminais de Walter Benjamin (2000), mas sublinhamos que as escolhas temáticas foram aqui feitas em virtude das conexões possíveis com Pauliceia desvairada e Eles eram muitos cavalos.

${ }^{6}$ Em francês, a palavra énormité tem um significado que escapa à tradução para o português: uma grande falta, uma besteira, um desvio. Cremos que tal significado, a par da ideia de grandiosidade física que se explicita na tradução, é importante para a compreensão da relação que se estabelece entre o eu-lírico e a cidade.
} 
A leitura de cada um dos fragmentos comprova a imersão absoluta de um "olhar" na própria vida da cidade que é seu objeto de atenção. Em todos eles a instância que sustenta tal olhar por meio da voz que narra (narrador? eu-lírico?) está imersa nos pequenos e, na maioria das vezes banais, acontecimentos que parecem emergir de cada esquina da cidade moderna: a velha que se reconhece decrépita nos olhos da criança, o carroceiro que vergasta o asno, a mãe que transforma em relíquia comercializável a corda que enforcou seu filho, o salão de jogos da boemia, o encanto sedutor de uma mulher... Contudo, no referido epílogo, há um movimento que pressupõe um distanciamento desse olhar que se afasta depois de ter vivido para, então, refletir sobre o que experimentou, em um esforço moderno de apreensão racional e, sobretudo, totalizante da experiência. Tal olhar/voz mergulha no mundo fabuloso da cidade moderna, impregna-se com o que ela lhe oferece de sedução e decrepitude, mas é consciente o bastante para saber refletir sobre esse mundo do movimento, das desigualdades, do automatismo, da exploração em uma parcela de tempo que é só sua - o amanhecer, momento em que ainda não se levantaram os trabalhadores e já se recolheram os boêmios - em um espaço que é só seu - o topo da montanha, lugar reservado do torvelinho das ruas. É essa consciência, esse tempo e espaço particulares o relicário do artista e que o mantém a salvo da ação desumanizante que a cidade moderna (e, claro, o sistema político-econômico que a erigiu e a sustenta) exerce sobre os outros.

O movimento ambíguo que contamina o olhar do artista sobre a cidade moderna está, no epílogo, metaforizado pela imagem da cidade-prostituta a que se lança o olhar poético em busca de rejuvenescimento (de formas poéticas? de temas poéticos?). Friedrich (1991, p. 38) nota que o conceito de "prostituição" é recorrente em Baudelaire, assumindo significados relacionados ao "abandono de si próprio, renúncia ilícita do destino espiritual, fuga ao campo alheio, traição por meio da dispersão" (que são, segundo Baudelaire) "os sintomas da civilização moderna". Ainda, assim, embora marcada pela negatividade impressa no significado baudelairiano de prostituição, a cidade se revela como uma das fontes de material do poetar moderno de que o artista não pode renunciar sob o risco de não se vincular ao presente e, assim, renunciar à própria modernidade.

Estar suficientemente perto da cidade para dela sorver o que há de mais expressivo na Modernidade que se consolida; estar suficientemente dela distanciado para não se deixar sorver por seu ritmo alienante: é esse o desafio do olhar poético que se detém nos centros urbanos em meados do século XIX. 
Se tal olhar, altamente consciente, moderno, sabe identificar as mazelas da cidade moderna ("De onde posso contemplar a cidade inteira,/ Hospital, lupanar, purgatório, inferno, prisão") lamentá-las, apenas, não se lhe oferece como alternativa ("Sabes bem, ó Satã, dono de minha angústia,/Que eu não fui lá para derramar meu pranto;") e embora o olhar poético se encontre em um tempo-espaço "separado" da cidade, é curioso notar que a metáfora utilizada para descrever tal ato de observação é a do envolvimento sensual ${ }^{7}$, do contato íntimo, o que aponta, mais uma vez, para aquele movimento dialético de aproximação $e$ distanciamento que já mencionamos anteriormente.

A estrutura poética escolhida por Baudelaire para a representação da cidade moderna e das relações sociais que aí se estabelecem é explicada pelo próprio poeta na introdução ${ }^{8}$ de sua obra. Tal passagem tem sido amiúde utilizada para explicar a maneira como a sensibilidade baudelairiana captara a necessidade de elaboração de um novo formato poético que fosse capaz de representar uma nova situação histórico-social:

Qual de nós, em seus dias de ambição, não sonhou o milagre de uma prosa poética, musical, sem ritmo e sem rimas, tão macia e maleável para se adaptar aos movimentos líricos da alma, às ondulações do devaneio, aos sobressaltos da consciência?

É, sobretudo, da frequentação das enormes cidades e do crescimento de suas enumeráveis relações que nasce esse ideal obsessivo. (Baudelaire, 2006, p. 17)

Sublinhe-se que, mais do que ajustar a forma do poema à realidade que se lhe impõe, o poeta ressalta como tal formato ajusta-se, antes, à sensibilidade do artista, essa sim, marcada pela "frequentação das grandes cidades". Tal aspecto dirime, de certa forma, a sensação de certo automatismo na relação entre realidade-representação que se pode identificar em algumas leituras críticas da obra de Baudelaire.

Além da estrutura da prosa poética arriscada por Baudelaire, há que se identificar que a reunião de textos diversos sobre a cidade moderna e seus habitantes era um formato recorrente durante o século XIX. Walter Benjamin (2000), ao discutir a multidão, esse objeto de representação

\footnotetext{
${ }^{7}$ Berman (2010, p. 175) observa que a postura artística de Baudelaire pressupõe o "épousement" (casamento/envolvimento sensual) em relação à vida de homens e mulheres na multidão, chamando atenção para o fato de que a arte, para Baudelaire, tem que estar muito próxima do cotidiano ao qual representa e problematiza.

${ }^{8} \mathrm{Na}$ verdade, trata-se de uma carta endereçada ao poeta Arsène Houssaye, incorporada à coletânea de poemas como uma espécie de prólogo.
} 
que surge a partir do surgimento das grandes cidades, remete aos "panoramas" e "fisiologias", obras de cunho descritivo, que se ocupavam do modo de vida pequeno-burguês e cuja tonalidade absolutamente amena distanciava-se sobremaneira da realidade tal qual se apresentava. O filósofo chama a atenção para o fato de que a elaboração dessas obras obedecia a uma imperiosa necessidade de acomodação a uma nova realidade que se impunha com a explosão demográfica das grandes cidades. E isso se promovia a partir da representação amistosa e inofensiva da multidão.

Se a obra de Baudelaire tem algum tênue vínculo com os panoramas e fisiologias, este se limita à motivação de representar a sociedade moderna que se erigia junto com a cidade moderna. No entanto, sua motivação não é a mesma, sequer o resultado que alcança. Os Pequenos poemas em prosa não se vinculam à bonomia de tais obras, mas também não se inclinam de todo à literatura que, de certo modo, sucedeu os panoramas e fisiologias no que diz respeito à representação da cidade e que se "atinha aos aspectos inquietantes e ameaçadores da vida urbana" (Benjamin, 2000, p. 45) desdobrando-se, posteriormente, no romance policial.

Há, em Baudelaire, a presença da multidão, mas ela está in absentia e não assume o papel ameaçador nem da turba revoltosa, nem da massa que oculta o marginal. Saem da multidão as figuras que povoam os Pequenos poemas em prosa, mas tais figuras importam enquanto parte representativa do todo social e assim é que são representadas9.

O fragmento XII dos Pequenos poemas em prosa é o único que se dedica às "Multidões" enquanto massa coletiva informe e despersonalizada. Curioso notar, entretanto, que a partir da motivação de descrever a multidão o poeta descreve, outrossim, a sua relação particular com ela, ressaltando o fato de que tal relação não se estabelece pela via da simples identidade, o que faria do poeta qualquer um, mas sim, pela da diferença, o que lhe garante uma posição privilegiada no interior da massa, a de "ser ele mesmo e um outro" (Baudelaire, 2006, p. 67-8). A diferença se estabelece, reiterando o disposto no epílogo, pela possibilidade que tem o poeta - e só ele - de se reservar: "Multidão, solidão: termos iguais e conversíveis pelo poeta ativo e fecundo. Quem não sabe povoar sua solidão também não sabe estar só no meio da multidão ocupadíssima". O poeta "desposa" a massa, se "embriaga" com ela em "orgias" sensuais, mas é no silêncio de sua solidão que pode refletir sobre as suas experiências e, sem ser levado

\footnotetext{
${ }^{9}$ Berman (2010, p. 178 e ss.) desenvolve análise iluminadora de um dos poemas, “Os olhos dos pobres" que pode vir a corroborar essa leitura. O poema "O Saltimbanco" também é exemplar desse procedimento.
} 
de roldão pelos acontecimentos que fustigam o homem moderno-produtivo, pode transformá-las em material poético.

\section{Mário de Andrade, de São Paulo à Pauliceia}

A dimensão do processo de urbanização pelo qual passou a cidade de São Paulo, no início do século XX, e a maneira pela qual foi conduzido, apoiado, sobretudo, na consolidação do capital industrial, não tinham precedentes no Brasil, até então. As profundas modificações no tecido urbano não se limitavam à materialidade arquitetônica da cidade, que teve que adaptar suas moradias para acolher o fluxo crescente de imigrantes do próprio país e do estrangeiro, acomodar as edificações industriais que então surgiam, abrir as vias de circulação para os veículos motorizados que deveriam transportar no ritmo veloz da modernidade os seus habitantes e os seus produtos. Essa nova materialidade urbana produziu traços simbólicos que contaminaram as relações sociais estabelecidas na cidade e forneceram material temático e motivação formal para os diversos produtos culturais que circularam pela São Paulo no início do século XX.

Mário de Andrade (1978, p. 236), em reflexão posterior sobre o Modernismo brasileiro e sobre o evento público, a Semana de Arte Moderna, que lhe serve de marco cronológico, aponta que

o Modernismo só podia mesmo ser importado por São Paulo e arrebentar na província. (...) São Paulo era espiritualmente muito mais moderna porém, fruto necessário da economia do café e do industrialismo consequente. Caipira de serra-acima, conservando até agora um espírito provinciano servil, bem denunciado pela sua política, São Paulo estava ao mesmo tempo, pela sua atualidade comercial e sua industrialização, em contato mais espiritual e mais técnico com a atualidade do mundo.

O que se tem é uma cidade em revolução que, a um só tempo, fornece temas e imagens aos produtos culturais da época e serve de argumento a um discurso revolucionário e modernizante que se consolidava no início do século XX, no Brasil. Exemplos são fartos na imprensa que, na épo$\mathrm{ca}$, encontrava-se em desenvolvimento espetacular e, segundo Schpum (2003, p. 12-3), é possível construir um inventário de "imagens que, metaforizando positivamente a modernidade, como fruto e casa de chegada do progresso, constroem uma ligação privilegiada entre esta e a cidade de São Paulo, transformando tudo que é lido como moderno em obra e prerrogativa paulistana". Nesse sentido, algumas imagens concretas assumem conotação simbólica quase sempre positiva que, a partir de sua 
reiteração, criam um imaginário moderno acerca da São Paulo do início do século: os prédios - normalmente descritos como muito mais altos do que eram efetivamente - a iluminação, as chaminés das indústrias, os automóveis:

Realmente, esta cidade, marulhenta de vida e semeada de arranhacéos, verdadeiro escrínio de bellezas architectonicas e esculpturaes, encanta e deslumbra, pelo seu conjunto artístico e sumptuoso, a todos que a contemplam.

Observada à noite, do alto de qualquer de suas interessantes collinas, a capital paulista dá-nos a ideia de um immenso amphitheatro, imerso num vasto oceano de luzes, cuja belleza ainda tem, a realçar-lhe o conjuncto, a bizarria dos innumeros annuncios luminosos, projectados dos cimos dos seus arranha-céos. Observada de dia, das mesmas alturas, as chaminés das suas innumeras fabricas, a confundirem os seus espessos pennachos de fumo com as nuvens que passam, lembram-nos Manchester, o maior parque industrial europeu. (Renais, apud Schpum, 2003, p. 25)

Este e outros discursos encomiásticos sobre a grande cidade e/ou sobre a modernização, não podem ser interpretados como os únicos paradigmas da representação da cidade no início do século XX. As vozes dissonantes existiam e deixavam entrever a dimensão humana que tais discursos deliberadamente ignoravam em favor da construção de uma imagem de progresso que deveria ser alcançado a qualquer custo. São Paulo também tinha, no início do século XX, "os olhos dos pobres". É o discurso literário, nesse caso, que diferentemente dos discursos oficiais e, mesmo, daqueles veiculados pela grande imprensa, expõe as fissuras de um processo de modernização urbana anunciado como irreversível e absolutamente positivo.

Pauliceia desvairada pode ser lida como uma obra programática do Modernismo brasileiro. Lá estão, realizadas poeticamente, as principais diretrizes de uma lírica que se queria renovadora da linguagem e dos temas literários de então. Julgamos que perseguir a imagem da cidade nesta obra de Mário de Andrade é, a um só tempo, compreender de que maneira a obra se ata aos principais proclames da modernidade literária, da qual é confessadamente tributária, e entender a maneira pela qual o tema da cidade grande, da metrópole cultural - moderno por excelência, como temos apontado - insere-se em um contexto particular de representação, que é o Brasil do início do século. Se as Villes Tentaculaires, de Verhaeren, 
forneceram a Mário a inspiração inicial para os seus versos livres ${ }^{10}$, é inegável o quanto a cidade de São Paulo se mostrava sedutora como material poético, uma vez que fornecia elementos materiais e também subjetivos que eram a promessa e, ao mesmo tempo, a prova do progresso anunciado pela modernização.

Somam-se, na Pauliceia desvairada, a revolução física pela qual passava a cidade e que foi testemunhada pelo artista, o desejo da modernidade cultural - e, por conseguinte, a recusa ao provincianismo - que, como foi apontado anteriormente, encontrava na imagem forjada da cidade um exemplo concreto, as ressonâncias poéticas de outras obras que já tinham elegido a realidade urbana tocada pela modernização como tema e motivação estética. Contudo, lá está, também, a face oposta da modernização, expressa por meio de versos cujo tom crítico desnuda a consciência que tem o poeta moderno de que a cidade, sua "inspiração", não se lhe oferece tão somente como musa.

Reflexões sobre a obra de Mário (Facioli, 2009; Nunes, 1984), e não apenas sobre Pauliceia desvairada, apontam para o fato de que ele foi o primeiro poeta modernista a pressentir as contradições do violento processo de modernização pelo qual atravessava a cidade de São Paulo no início do século passado, e a eleger tal questão como temática recorrente de sua obra. Contudo, para os limites deste artigo, nos deteremos na discussão sobre como Mário de Andrade incorporou tais contradições na representação dos temas/imagens explorados por Baudelaire cerca de 60 anos antes.

* a rua, a multidão, os olhos que veem a cidade

São Paulo é percorrida geograficamente em Pauliceia desvairada. É possível, perseguindo os versos da obra em questão, traçar diferentes percursos pela cidade, acompanhando, sempre, muito mais do que descrições espaciais - embora as ruas e espaços públicos sejam tratados nominalmente com frequência - as sensações e imagens que a cidade imprime na sensibilidade do eu-lírico. Localizam-se, nos versos marioandradinos: a Rua Marechal Deodoro, a Rua da Consolação, a Avenida Paulista e o Parque Trianon, o

\footnotetext{
10 No seu “O movimento modernista”, espécie de balanço crítico-sentimental do Movimento Modernista e da Semana de Arte Moderna, Mário de Andrade informa: "Eu passara esse ano de 1920 sem fazer poesia mais (...) Na minha leitura desarvorada, já conhecia até alguns futuristas de última hora, mas só então descobrira Verhaeren. E fora o deslumbramento. Levado em principal pelas Villes tentaculaires, concebi imediatamente fazer um livro de poesias "modernas", em verso livre, sobre a minha cidade" (Andrade, 1978, p. 233).
} 
Cambuci, o Anhangabaú, a Moóca, o Largo de São Bento... Uma São Paulo ainda pequena se comparada às suas proporções atuais, mas suficientemente grande e culturalmente diversificada para a percepção do início do século. Além disso, o que é um aspecto muito significativo da obra, uma São Paulo na qual convergem tempos distintos: de um lado a São Paulo "em via de se transformar na grande cidade industrial sul-americana, onde o novo começa a sobrepujar o velho", de outro "um passado provinciano, de missas na Igreja de Sta. Cecília, de passeios nos parques" (Nunes, 1984, p. 65).

Também se localizam na obra, dispersas em metáforas, imagens e sugestões sonoras, um tom que se avizinha da lúgubre lamentação, o que, de certa forma, mostra-se dissonante ao se ter em vista a percepção corrente de que Pauliceia desvairada seria uma representação eufórica da cidade moderna recém-surgida. Nesse sentido, imagens como a da flor, que abre o poema "Tristura", em epígrafe tirada de Mallarmé e aparece, também, no poema "Paisagem N. 1"11 e o adjetivo de grande potência imagética "arlequinal", empregado recorrentemente, sublinhando a positividade da diversidade cultural observada na São Paulo do início do século, se contrapõem à insistente caracterização da cidade como cinza, fria, nebulosa.

Esse itinerário geográfico-lírico obedece aos ditames da percepção da arte moderna sobre a modernização urbana. Pauliceia desvairada é um hino que faz homenagem à cidade de São Paulo, uma vez que a sabe como fonte de material poético. Ao mesmo tempo, é válvula de escape para a percepção do artista acerca de tudo o que se perde(rá) com tal modernização, o que resulta, frequentemente, em exposição subjetiva do eu-lírico.

Tal característica da obra de Mário que temos lido é objeto de discussão de Luiz Costa Lima (1995) em ensaio já clássico. Nele, o crítico discute como a dicção moderna da linguagem de Mário de Andrade nasceu juntamente com a consciência da modernidade do objeto a qual deveria representar, e que "a cidade, matéria do poema, não pode(ria) ser identificada e julgada senão por uma ótica alimentada por sua linguagem específica" (Lima, 1995, p. 65). Antes, porém, de alcançar o pleno desenvolvimento dessa linguagem específica, Mário de Andrade recorreria, segundo Costa Lima (id., p. 58), ao que ele denominou "consumo privado" na representação das imagens da cidade, o que faria com que a grande maioria dos poemas de Pauliceia desvairada não se realizasse plenamente no que diz respeito à representação da cidade, uma vez que, “da busca de incorporála expressionalmente ao verso, surge um sucessivo deslizar para o consumo privado daquilo que ela entrega", o que, segundo o crítico, desvelaria uma feição romântico-passadista da primeira poesia marioandradina.

${ }^{11}$ Ver a análise dessa metáfora em Fonseca (2008). 
Sem entrar no mérito da proposta de valoração de alguns poemas de Pauliceia desvairada em detrimento de outros, que derivam dessa percepção crítica, o que nos interessa apontar, nos limites deste artigo, é o fato de que há, na obra em questão, um travo subjetivo, uma identificação entre o eu-lírico e a cidade que lhe serve de objeto de representação que nos parece distante da postura baudelairiana de investigar a cidade do alto, de ser "ele mesmo e um outro ao mesmo tempo" (Baudelaire, 2006, p. 67). Mário, na percepção de Costa Lima, não abre mão de investigar o seu ego... mesmo quando investiga a cidade.

É possível observar na obra uma oscilação entre a representação líricosentimental da cidade e a representação irônico-crítica da cidade. De um lado, o poema "Inspiração", de outro, o poema "Os cortejos"; entre os dois extremos uma série de poemas que fazem deslizar a percepção positiva da cidade para uma percepção negativa - e vice-versa - oscilação que não se faz apenas tematicamente, mas também pela escolha de recursos expressivos específicos. Nos dois casos, a sempiterna presença do olhar do eu-lírico que insiste em apontar para o fato de que a cidade-objeto da poesia encontra-se menos na materialidade de suas construções, ruas, pessoas que a habitam e mais na percepção subjetiva do poeta. Daí a recorrência de expressões que submetem a cidade ao eu-lírico por meio do olhar: "Monotomias de minhas retinas..." (...) "Estes homens de São Paulo (...)/quando vivem dentro dos meus olhos tão ricos..." ("Os cortejos"), "Oh! minhas alucinações!/Vi os deputados..." ("O rebanho"), “Mas... olhai, oh meus olhos saudosos dos ontens" ("O Domador").

\section{Eles eram muitos cavalos e a São Paulo pós-utópica}

A narrativa contemporânea que se volta para a apreensão não só do espaço, mas também - e, talvez, sobretudo - da sociabilidade urbana se constitui a partir de pelo menos duas ordens de elementos: de um lado, o objeto em si da representação, a cidade contemporânea e sua realidade por vezes inapreensível e inenarrável, o cotidiano eivado pela violência de toda ordem, as drásticas disparidades sócio-econômicas, a convivência dos contrastes culturais, as pequenas e grandes tragédias... de outro lado, a tradição literária que, desde a aurora da modernidade elegeu o espaço urbano como fonte de interesse e desenvolveu, para a sua representação, meios expressivos específicos que passaram a apreender o que, na passagem do século XIX para o século XX era de extrema novidade: a velocidade, a multidão, o processo de industrialização... A questão que se coloca da convivência entre essas duas ordens de elementos diz res- 
peito a quanto dos recursos expressivos modernos, que se consolidaram justamente enquanto se consolidava a cidade moderna, está presente na literatura brasileira contemporânea, bem como de que forma tais recursos são mobilizados para tratar de uma realidade específica e de seus ecos subjetivos, hoje tão diferentes.

Nesse sentido, não se trata apenas de uma análise das diferenças físicas, sociais, econômicas entre a grande cidade do século XIX e a cidade de hoje ou, mais especificamente, entre a São Paulo do início do século XX e a São Paulo do início do século XXI, mas da análise de uma certa imagem da cidade construída por meio da representação literária, a partir de meios expressivos que, se surgiram e se consolidaram a partir da consolidação da cidade moderna, com a finalidade específica de representar/ recriar esteticamente uma realidade que se impunha, parecem sobreviver ao aniquilamento da ideia de cidade moderna como espaço do vir-a-ser, servindo, agora, para a representação das ruínas do projeto moderno de progresso urbano.

Passados dez anos de sua publicação, o romance de Luiz Ruffato, Eles eram muitos cavalos já acumulou considerável fortuna crítica, composta por análises e reflexões que versam sobre um sem-número de temas que estão na ordem do dia quando se trata da prosa contemporânea brasileira: a violência, a representação das minorias, a representação da cidade, o realismo traumático etc. Muitas das discussões a respeito do romance atentam, também, para a sua estrutura composicional, fragmentária, elíptica, caótica, construída a partir de uma multiplicidade de pontos de vista que arregimentaria um vago sentido de totalidade a partir de um procedimento que Andrea Saad Hossne (2007) identificou como "acumulação". Os conceitos de montagem e de colagem também frequentam as análises críticas do romance e nem sempre vinculam tais procedimentos ao surgimento de uma linguagem literária - e também plástica e cinematográfica - que remonta ao início do século XX e que não são, portanto, novidades do ponto de vista expressivo, podendo ser atreladas a uma tradição de representação da sensibilidade moderna.

Duas afirmações de Luiz Ruffato alimentam a discussão:

Do meu ponto de vista, para levar à frente um projeto de aproximação da realidade do Brasil de hoje, torna-se necessária a invenção de novas formas de apreensão dessa realidade. Escrever romances baseando-se nas premissas do século XIX para descrever o caos do século XXI me parece um contrassenso. Por isso, acredito na busca de novas formas de expressão, em que a literatura dialoga com outras artes (música, artes plásticas, teatro, cinema etc.) e tecnologias (inter- 
net, por exemplo) para a criação de uma linguagem que exprima esse novo indivíduo. (Segundo Caderno, O Globo, 1 de agosto de 2003).

Ora, se os acontecimentos externos podem modificar nossa constituição de seres humanos (...) então devemos admitir que somos obrigados a idear novas formas de compreendermo-nos imersos neste mundo repleto de múltiplas significâncias. Continuar pensando o romance como uma ação transcorrida dentro de um espaço e num determinado tempo, e que pretende ser o relato autêntico de experiências individuais verdadeiras, passa a ser, no mínimo, anacrôncico. (Conferência apresentada no $4^{\circ}$ Assises internationale du roman, 2010)

Quais seriam, então, essas "novas formas" de apreensão de realidade a que se refere Luiz Ruffato? E, no caso de não serem assim tão "novas", o que faz com que elas tenham sentido renovado em Eles eram muitos cavalos $^{12}$ ?

O romance de 2001 se passa em São Paulo, mas é evidente que não se trata mais da São Paulo marioandradina, que via nascer as contradições e desigualdades que caracterizam, pelo paroxismo, a São Paulo do século XXI. O recurso da personificação que está presente em tantos dos poemas de Pauliceia desvairada e que também surgira no epílogo do Spleen de $\mathrm{Pa}$ ris não se apresenta em nenhum momento no romance de Ruffato. Nos dois casos mencionados, mesmo que com sentido e, sobretudo, valores diferentes dos diversos poemas de Mário e no poema de Baudelaire, a personificação permite uma aproximação entre o objeto de representação e o eu-lírico que deixa entrever o envolvimento subjetivo entre aquele que observa e o seu foco de interesse.

Baudelaire, como vimos, trata tal envolvimento, "épousement", em termos sensuais, portanto a partir de uma sensibilidade física recorrentemente aproximada ao conceito de "prostituição" que permitia ao eu-lírico "ser ele mesmo e um outro", ser ele mesmo e ser a cidade e seus habitantes, ao mesmo tempo, graças à sua disponibilidade de misturar-se à multidão e depois recolher-se para fruir suas experiências e torná-las objeto estético.

Mário estabelece tal comunhão afetiva com a cidade que ela parece emergir de sua própria sensibilidade. Para tanto, o eu-lírico não precisa propriamente confrontar-se com a cidade, nem misturar-se à multidão de suas ruas, uma vez que o seu objeto de representação lhe está interiorizado - e isso se pode ler na maioria dos poemas em que a identificação entre São Paulo e o eu-lírico se exprime pelo emprego insistente dos pos-

${ }^{12}$ De agora em diante adotaremos a abreviação EEMC para nos referirmos ao romance. 
sessivos ("São Paulo, comoção de minha vida!") e pelos deslizamentos metafóricos que carreiam as mesmas imagens para uma e outro.

Em EEMC o distanciamento afetivo entre a cidade e seus habitantes seja de quais classes sociais forem, habitem quais espaços habitarem nesse espaço urbano - se expressa pela ausência de uma voz/foco únicos. Se a fragmentação, expressa por meio de procedimentos como a montagem e a colagem, não é novidade expressiva (e poder-se-iam enumerar várias obras de arte, plásticas, literárias, cinematográficas que, desde as vanguardas artísticas, na passagem do século XIX para o século XX, utilizaram-se desse procedimento para representar uma realidade cada vez mais descontínua, heterogênea e fugaz), neste romance ela se configura de modo diferente quando não cede a qualquer princípio organizador de perspectiva ou narração. A ausência de uma voz única que narre a cidade e de um olhar único que tente compreendê-la impossibilita qualquer sentido de identificação positiva ou negativa entre aquele (quem?) que observa e o seu objeto de atenção. Os riscos de tal opção formal relacionam-se com a banalização da violência, cuja exposição "impessoal" (leia-se livre de um envolvimento emocional que se expresse por meio da eleição de uma voz/perspectiva única que denuncie, revolte-se, resigne-se...) poderia se aproximar da sucessão das cenas do último jornal da noite. Não obstante, não é o que ocorre. EEMC não é um romance eticamente insípido e o seu senso de crítica social se constrói pelo sentido da acumulação identificado por Andréa Saaad Hossne. A acumulação de cenas, personagens, vozes e perspectivas faz reverberar, para o leitor, menos o que foi narrado e descrito e mais o que ficou em suspenso dessas inúmeras histórias fragmentárias que possivelmente teriam inícios e desfechos para além das páginas do livro. Continuar a ler as histórias narradas no romance, mesmo quando elas se interrompem abruptamente é a tarefa do leitor, que precisa sair do romance e entrar na vida para dar conta disso.

Nesse sentido, se a Paris baudelairiana é tema e espaço em que se captam a nova vida que emergia com o desenvolvimento acelerado das grandes cidades, se a São Paulo marioandradina é tema e personagem que compartilham com o eu-lírico os seus traços característicos (desvairada é a cidade, mas é, também, o poeta), a São Paulo de EEMC é a micro e poliexemplaridade do fracasso de um projeto de urbanização. As cenas, sketchs, fragmentos que compõem o livro dão notícia da sociabilidade em um espaço no qual o "social" inexiste, soterrado nas trincheiras do medo e da miséria. Assim, se o espaço de São Paulo é essencial para a representação da realidade urbana tecida pelo romance, ela pode ser vista também em termos de exemplaridade, apontando para tantas outras e diferentes 
realidades que, urbanas ou não, comunga(ra)m do mesmo modelo falido de modernização.

Aqui, explicita-se mais uma diferença em termos de representação da cidade de São Paulo por Mário de Andrade e por Luiz Ruffato. Em Pauliceia desvairada acumulam-se signos, imagens que distinguem a cidade de tantas outras cidades em desenvolvimento no início do século XX. Tais signos e imagens - o bandeirante, o imigrante, o Rio Tietê, a velocidade dos automóveis, a verticalidade, o clima - individualizam a cidade, o que se evidencia, sobretudo, pela escolha de um título que recolhe em si o nome da cidade que representa.

A recusa de uma voz e de uma perspectiva únicas, ou, pelo menos, identificáveis em sua multiplicidade, constrói, ainda, outros efeitos de sentido no romance de Ruffato. Se a degeneração da sociabilidade é sentida por todos os habitantes da cidade, é patente o fato de que ela os atinge de maneiras diferentes e, nesse aspecto, a opção formal do romance coloca em evidência de forma crítica e literariamente formulada a mensagem diariamente reiterada pelo jornal televisivo: aos pobres a cidade se mostra mais cruel. Capítulos como o de número 16, "assim", e o de número 27, "evangelista", expõem isso a partir de uma das alternâncias físico-espacial que serão recorrentes na obra ${ }^{13}$. No primeiro caso, a cidade vista "de cima", do helicóptero, por quem diagnostica a miséria sem dela aproximar-se, embora por ela lateralmente afetado, via violência urbana. Aqui, os signos da pujança se acumulam: além do helicóptero, meio de transporte dos que não podem/não devem se submeter ao ritmo lento da cidade grande, o notebook, os filhos que estudam ou trabalham no exterior em contraponto às críticas desfiadas a respeito da cidade e que se sustentam numa imagem idealizada da São Paulo "perdida" do início do século. O contraponto é construído a expensas de frases que se intercalam:

- não sou insensível à questão social irreconhecível o centro da cidade hordas de camelôs batedores de carteira homens sanduíche cheiro de urina cheiro de óleo saturado cheiro de a mão os cabelos ralos percorre (minha mãe punha luvas, chapéu, salto alto para passear no viaduto do chá, eu, menino, pequenininho mesmo, corria na) este é o país do futuro? deus é brasileiro? onde ontem um manancial hoje uma favela onde ontem uma escola hoje uma cadeia onde ontem um prédio do começo do século hoje um três dormitórios suíte setenta metros quadrados. (Ruffato, 2001, p. 36-7)

E que, para além de romper a linearidade sintática, promovem a ruptura

${ }^{13}$ Em artigo anteriormente citado, desenvolvo essa reflexão a partir da alternância “dentro” versus “fora”. 
da hegemonia do significado: tornam-se tristemente irônicas as percepções críticas a respeito do espaço urbano, corroídas por um ponto de vista que se locupleta no distanciamento de quem, de fato, não vive a cidade, o que é materialmente explicitado pelo não contato físico com ela. Qual envolvimento possível existe entre a cidade e quem a vê de cima - do helicóptero - e de fora - dos vários países europeus que são citados no capítulo?

Em oposição a essa perspectiva, o capítulo 27 , e tantos outros, em que a cidade surge materializada sob os pés de quem nela vive/sobrevive. Nesse caso, o interessante é notar de que forma o espaço urbano toma corpo e parece devorar aqueles que não podem dele se resguardar em helicópteros, automóveis blindados, condomínios de luxo:

A seus olhos, caótica, a Praça da Sé espicha-se, indolente. Sozinho, perfila-se à boca das escadas rolantes que esganam as profundezas do metrô. (...)

E, súbito, um como que monolito esmaga seu peito abafando a sinfonia da tarde explodindo-a em blecautes

alguns segundos? minutos? um par de sapatos um par de tênis solas gastas aproximam-se bitucas folhas copos descartáveis pombos guardanapos palitos papéis de bala poça de mijo. (id., p. 59)

Nesse capítulo, o personagem, nocauteado pela opressão a que é submetido, cai. A queda, sem deixar de ser simbólica, já que metaforiza o seu fracasso em pregar a palavra de Deus, é narrada de forma concreta: o chão é o da cidade, a sujeira é a da cidade, espaço inóspito em que não há lugar para a redenção de qualquer tipo.

Ainda inserido nessa questão da alternância entre os espaços físicos que acarretam a alternância entre uma perspectiva distanciada e outra aproximada em relação à cidade, há que se sublinhar que estão a cargo dos personagens colocados "a salvo" do espaço físico opressor as reflexões a seu respeito. Àqueles que precisam enfrentar a cidade diariamente não refletem sobre ela, são simplesmente devorados por ela. Contudo, a partir do procedimento que já descrevemos quando da análise do capítulo 16, as manifestações críticas dos personagens que vivem na cidade mas desenvolveram estratégias para se afastarem de seus problemas mais comuns, como o trânsito e a violência, são corroídas, minadas desde o seu interior, e, para o leitor, mobilizam significados relativos a um posicionamento cínico, recorrente em alguns estratos da elite econômica que, embora tirando proveito dos esquemas financeiros e de poder que garantem altos lucros para poucos e a miséria para muitos, não querem arcar com as terríveis consequências sociais daí resultantes. 


\section{Considerações finais}

As conclusões modestas a que se pode chegar nos limites deste artigo apontam para o fato de que a cidade moderna surge como tema literário caro à literatura moderna por ser o repositório das utopias de progresso sobre as quais repousa o próprio projeto de modernidade. Desde os panoramas e fisiologias que tentavam dar conta da nova realidade urbana, passando pela literatura produzida no início do século XX, projeta-se uma imagem de cidade que corresponde às ambivalências constitutivas da própria modernidade: de um lado, o lugar do vir-a-ser do progresso material (quiçá espiritual), que reúne as utopias iluministas, de outro, o lugar que revela, de forma cada vez mais profunda, as desigualdades inerentes do sistema capitalista que, não esqueçamos, é a base material da modernidade. $\mathrm{O}$ resultado, como tentamos expor na discussão a respeito da obra marioandradina, é a convivência de imagens, símbolos e formas poéticas que carreiam tais ambivalências. E o adjetivo "arlequinal", tão recorrente em Pauliceia desvairada encontra mais um aspecto a que emprestar os seus signos de multiplicidade e polivalência.

No momento em que filósofos e historiadores discutem o fim da modernidade e diagnosticam o momento presente como pós-utópico, a cidade, antes ambivalente, tal qual a modernidade e suas promessas, passa a ser representada sem nenhum sentido eufórico: é o lugar em que o capitalismo mostra a sua face mais cruel e onde os preceitos do iluminismo já não têm mais lugar.

EEMC está diante dessa cidade, ao mesmo tempo em que tem, às suas costas, uma poética de representação do espaço urbano que data de, pelo menos, um século e meio e que foi construída pelos escritores modernos que, sem dúvida, são os que frequentam as estantes e as cabeças dos escritores contemporâneos. Como resolver esse impasse? Se a proposta de um escritor como Ruffato se mostra intrigante, eivada por um éthos moderno, quem sabe até de vanguarda - diante da nova realidade, construamos uma nova dicção literária -, o que se percebe amiúde e de maneira muito clara em EEMC é o uso dos procedimentos literários que remontam ao início do século XX com um outro intuito: representar, sem concessões a um utópico vir-a-ser $-\mathrm{e}$, portanto, sem nenhum apaziguamento - , o aqui e agora da cidade moderna.

\section{Referências bibliográficas}

ANDRADE, Mario (1987). "Pauliceia desvairada". In: Poesias completas. Edição crítica de Diléa Zanotto Manfio. São Paulo: Edusp/Itatiaia. 
(1978). Aspectos da literatura brasileira. 6. ed. São Paulo: Martins Fontes. BAUDELAIRE, Charles (2006). Pequenos poemas em prosa. Edição bilíngue. Trad. Gilson Maurity. Rio de Janeiro: Record. e Terra. (1997). Sobre a modernidade (O pintor da vida moderna). São Paulo: Paz

BENJAMIN, Walter (2000). Obras escolhidas. 3. ed. São Paulo: Brasiliense. v. 3. BERMAN, Marshall (2010). Tudo o que é sólido desmancha no ar. São Paulo: Companhia de Bolso.

BRADBURY, Malcolm; McFARLANE, James (Orgs.) (1999). Modernismo: guia geral. São Paulo: Companhia das Letras.

FACIOLI, Valentim (2009). "São Paulo capital Brasil (Mário de Andrade: literatura e modernização)". Revista Cerrados. Brasília: UnB. v. 18, n. 28.

FONSECA, Aleilton (2008). “Mário de Andrade: São Paulo é um rosal!". Légua e Meia. v. 6, n. 4.

FRIEDRICH, Hugo (1991). Estrutura da lírica moderna. 2. ed. São Paulo: Duas Cidades.

HAMBURGUER, Michael (2007). A verdade da poesia: tensões na poesia modernista desde Baudelaire. São Paulo: Cosac Naify.

HOSSNE, Andrea Saad (2007). “Degradação e acumulação: considerações sobre algumas obras de Luiz Ruffato". In: HARRISON, Marguerite Itamar (Org.). Uma cidade em camadas: ensaios sobre o romance Eles eram muitos cavalos de Luiz Ruffato. Vinhedo: Editora Horizonte.

KUMAR, Krishan (1997). Da sociedade industrial à pós-moderna: novas teorias sobre o contemporâneo. Rio de Janeiro: Jorge Zahar.

LIMA, Luiz Costa (1995). "Permanência e mudança na poesia de Mário de Andrade". In: Lira \& antilira. 2. ed. revista. Rio de Janeiro: Topbooks. p. 47-128.

NUNES, Benedito (1984). "Mário de Andrade: as enfibraturas do modernismo". Revista Ibero-Americana. v. L, n. 126.

ROCHA, Rejane Cristina (2009). "Arquitetura dos contrastes: uma leitura de Eles eram muitos cavalos". In: CAMARGO, Flávio Pereira; CARDOSO, João Batista (Orgs.). Percursos da narrativa brasileira contemporânea. João Pessoa: UFPB/Realize, 2009.

RUFFATO, Luiz (2010). Das impossibilidades de narrar. Texto da conferência apresentada no $4^{\circ}$ Assises internationales du roman. Lyon. Disponível em: $<$ http://www.conexoesitaucultural.org.br>.

. (2003). Entrevista concedida. Segundo Caderno, O Globo, 1 ago.

. (2001). Eles eram muitos cavalos. São Paulo: Boitempo.

SCHPUN, Monica Raisa (2003). "Luzes e sombras da cidade (São Paulo na obra de Mário de Andrade)". Revista Brasileira de História. v. 23, n. 46.

Recebido em agosto de 2011.

Aprovado em outubro de 2011. 


\section{resumolabstract}

\section{As formas do real: a representação da cidade em Eles eram muitos cavalos} Rejane Cristina Rocha

Este trabalho discute de que maneira a representação moderna da cidade - no que diz respeito à eleição de temas e às opções formais - pode ser identificada em um romance brasileiro contemporâneo: Eles eram muitos cavalos, de Luiz Ruffato, publicado em 2001.

Palavras-chave: literatura brasileira contemporânea, modernidade, representação da cidade

\section{Forms of real: the city's representation in Eles eram muitos cavalos}

Rejane Cristina Rocha

This work discusses the way by which the modern representation of city can be recognized, specially how it concerns to the choice of themes and to the formal options, in a Brazilian contemporary novel: Eles eram muitos cavalos, published by Luiz Ruffato in 2001.

Key words: brazilian contemporary literature, modernity, representation of city 